一論文—

（日本化学会誌，1995，（10），p. 809～815）

(C) 1995 The Chemical Society of Japan

\title{
ポリメチルベンゾフェノン類の選択的オルトメチル基へのニトロ化と アントラキノン類合成への応用
}

(1995 年 4 月 12 日受理)

森田俊夫*·藤井和代·多賀陽美・塚本宏樹·

高橋一朗・故毛海敬·北嶋 英彦

ポリメチルベンゾフェノン類 $(\mathbf{1} \mathbf{a} \sim \mathbf{1 j})$ の発煙硝酸/無水酿酸系によるニトロ化を行い, アシル基のオ ルト位メチル基が側鎖ニトロ化された 2-ニトロメチルベンゾフェノン類 $(\mathbf{2} \mathbf{a} \sim 2 \mathbf{j})$ を優先的に得た.

2 -及び 5 '-位にニトロ基及びクロロ基を持つ $\mathbf{2 a} \sim 2 \mathrm{~d}$ は 1,8-ジアザビシクロ[5．4．0]-7-ウンデン で処理すると分子内求核置換反応が起こり，ついで過マンガン酸カリウム，または二クロム酸ナトリウ ムで酸化すると相当するアントラキノン誘導体 $(\mathbf{3 a} \sim \mathbf{3 d})$ が得られた． $3^{\prime}$-または $3^{\prime}-$ 及び $5^{\prime}-$ 位にニト 口基のみ持つ $2 \mathrm{e} \sim \mathbf{2 j}$ は炭酸ナトリウムで処理すると分子内水素身代わり求核置換反応が起こり，つい で二クロム酸ナトリウムで酸化すると相当するアントラキノン誘導体 $(\mathbf{3 a} \sim \mathbf{3} \mathbf{f})$ が得られた.

\section{1 緒言}

メチル置換ベンゼン類のニトロ化反応はメチル基の側鎖置換反 応が起こることから興味が持たれ，活発に研究されてきた ${ }^{11}$ 。こ こで生成するニトロメチル基は種々の官能基に変換可能であり, さらに, ニトロ基により活性化されたメチレン炭素上での種々の 化学反応が期待される23).

著者らはアシルポリメチルベンゼン類を発煙硝酸/無水酿酸系 でニトロ化するとアシル基のオルト位メチル基が選択的に側鎖二 トロ化され，2-(ニトロメチル)アシルポリメチルベンゼン類が 得られることを見いだし4)，さらにこれら側鎖ニトロ化物の活性 を利用して，フタル酸誘導体4)，テトラロン類(5およびインダノ ン類6)を合成した。

これらの研究の一環として, ポリメチルベンゾフェノン類(1) から相当する側鎖ニトロ化物 (2) を経て, アントラキノン類(3) を合成したので報告する（四式 1).

アントラキノン誘導体はアントラキノンの置換反応, または芳 香族化合物と無水フタル酸を Friedel-Crafts 反応させ，ついで 分子内脱水反応により合成されている. 後者の方法では, 脱水過 程が過酷な条件を必要とするため, 多置換誘導体の場合, 位置選 択性の低下7)，異性化8)などを伴うことが知られており，このよ うな場合にはより温和な条件での合成が望まれる.

\section{2 実験}

\section{1 試料と測定}

記載の融点はすべて未補正である. IR スペクトルは日本分光 FT/IR-8000G 型赤外分光光度計を使用した. ${ }^{1} \mathrm{H}-\mathrm{NMR}$ スペク
トルは日本電子 $\mathrm{GX}-270 \mathrm{FT} / \mathrm{NMR}$ 分光光度計を用い, 重水素化 クロロホルムを溶媒, テトラメチルシランを内部標準として測定 した.
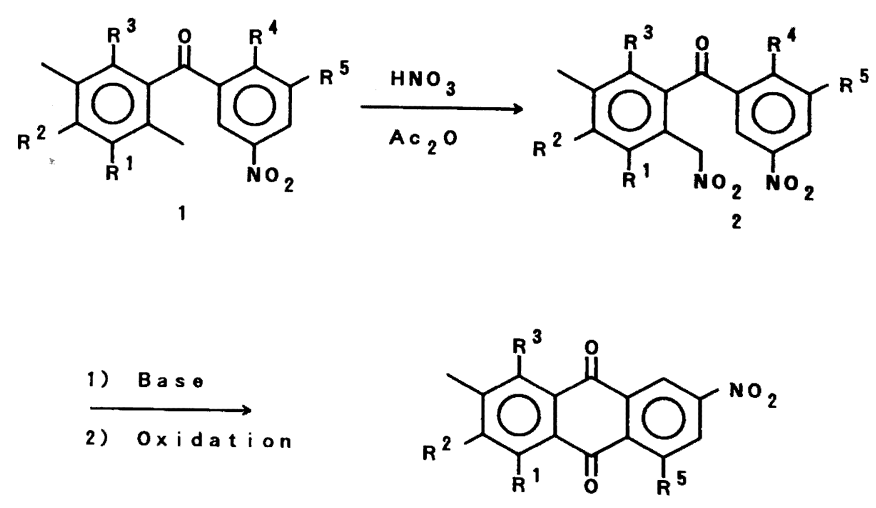

\begin{tabular}{l|lllll}
1,2 & $\mathrm{R}^{1}$ & $\mathrm{R}^{2}$ & $\mathrm{R}^{3}$ & $\mathrm{R}^{4}$ & $\mathrm{R}^{5}$ \\
\hline $\mathrm{a}$ & $\mathrm{CH}_{3}$ & $\mathrm{CH}_{3}$ & $\mathrm{CH}_{3}$ & $\mathrm{CI}$ & $\mathrm{H}$ \\
$\mathrm{b}$ & $\mathrm{H}$ & $\mathrm{CH}_{3}$ & $\mathrm{CH}_{3}$ & $\mathrm{Cl}$ & $\mathrm{H}$ \\
c & $\mathrm{H}$ & $\mathrm{CH}_{3}$ & $\mathrm{H}$ & $\mathrm{Cl}$ & $\mathrm{H}$ \\
d & $\mathrm{CH}_{3}$ & $\mathrm{CH}_{3}$ & $\mathrm{CH}_{3}$ & $\mathrm{CI}$ & $\mathrm{NO}$ \\
e & $\mathrm{CH}_{3}$ & $\mathrm{CH}_{3}$ & $\mathrm{CH}_{3}$ & $\mathrm{H}$ & $\mathrm{H}$ \\
f & $\mathrm{H}$ & $\mathrm{CH}_{3}$ & $\mathrm{CH}_{3} \mathrm{H}$ & $\mathrm{H}$ \\
9 & $\mathrm{H}$ & $\mathrm{CH}_{3}$ & $\mathrm{H}$ & $\mathrm{H}$ & $\mathrm{H}$ \\
$\mathrm{h}$ & $\mathrm{Br}$ & $\mathrm{CH}_{3}$ & $\mathrm{CH}_{3}$ & $\mathrm{H}$ & $\mathrm{H}$ \\
i & $\mathrm{H}$ & $\mathrm{OCH}_{3}$ & $\mathrm{H}$ & $\mathrm{H}$ & $\mathrm{H}$ \\
$j$ & $\mathrm{CH}$ & $\mathrm{CH}_{3}$ & $\mathrm{CH}_{3}$ & $\mathrm{H}$ & $\mathrm{NO}$ \\
\end{tabular}


ポリメチルベンゾフェノン類 $(\mathbf{1 a} \sim 1 \mathbf{j})$ は，相当するポリメチ ルベンゼン類と塩化ベンゾイル類の Friedel-Crafts 反応から合 成した，収率と特性値を表 1 に示した。

\section{2 ベンゾフェノン類 $(1 \mathrm{a} \sim 1 \mathrm{j})$ の側鎖ニトロ化}

反応例として，2'-クロロ-5'-ニトロ $-2,3,4,5,6$-ペンタメチル ベンソフェノン(1a) のニトロ化について述べる. $1 \mathrm{a}(2.00 \mathrm{~g}$, $6.03 \mathrm{mmol})$ の無水酢酸 $50 \mathrm{ml}$ 溶液へ, $99 \%$ 硝酸 $(0.84 \mathrm{~g}, 13.26$

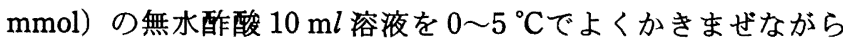
15 分間を要して滴下した，反応混合物を同温度で 10 時間かきま ぜた後, 約 $500 \mathrm{ml}$ の承水中に注ぎ，一夜かきまぜた．生成した 沈殿物を沪過し 2a の粗製品 $\left(2.23 \mathrm{~g}, 98 \%, \mathrm{mp} 181 \sim 8{ }^{\circ} \mathrm{C}\right)$ を得
た。エタノールから再結晶して精製品 $(1.64 \mathrm{~g}, 72 \%, \mathrm{mp} 194 \sim 5$ $\left.{ }^{\circ} \mathrm{C}\right)$ を得た。同様な方法で $\mathbf{2 b} \sim \mathbf{2 j}$ を合成した.

\section{3 分子内求核置換反応亡酸化反応}

2.3.1 $2 \mathrm{a} \sim 2 \mathrm{c}$ の場合：反応例として，2'-クロロ-5'-ニトロー 2-ニトロメチル-3,4,5,6-テトラメチルベンゾフェノン $(\mathbf{2 a})$ につ いて述べる. $2 \mathbf{a}(0.50 \mathrm{~g}, 1.33 \mathrm{mmol})$ のメタノール $30 \mathrm{ml}$, ジク ロロメタン $30 \mathrm{~m} l$ 溶夜へ，1,8-ジアザビシクロ [5．4．0]-7-ウン デセン $(\mathrm{DBU})(0.20 \mathrm{~g}, 1.33 \mathrm{mmol})$ のメタノール $10 \mathrm{ml}$ 溶液を室 温でよくかきまぜながら添加した，反応混合物を 4 時間煮沸し た後, $0 \sim 5{ }^{\circ} \mathrm{C}$ に冷却して水酸化カリウム $(0.074 \mathrm{~g}, 1.33 \mathrm{mmol})$ の水溶液 $2 \mathrm{~m} l$ を添加し, ついで過マンガン酸カリウム $(0.21 \mathrm{~g}$,

Table 1 Characterization of compounds $(\mathbf{1 a} \sim \mathbf{1 j})$

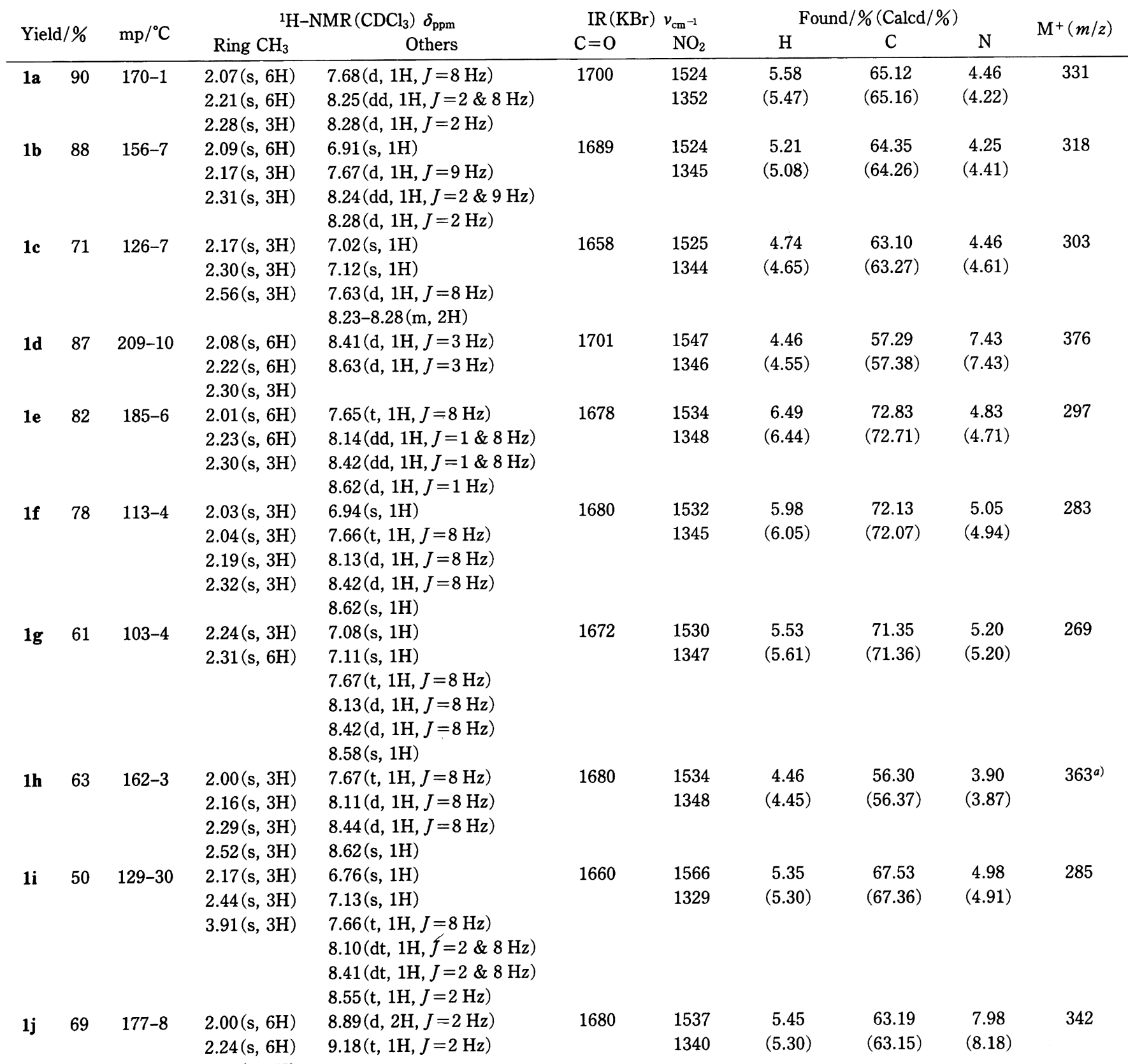

a) Isotopic peak by ${ }^{81} \mathrm{Br}$ was also observed. 
$1.33 \mathrm{mmol})$ と硫酸マグネシウム $(0.16 \mathrm{~g}, 1.33 \mathrm{mmol})$ の水溶液 $20 \mathrm{~m} l$ を45 分間要して滴下した，反応混合物を同温度で 2 時間 かきまぜた後，ジクロロメタンで抽出した．有機層を水洗した 後, 無水硫酸ナトリウムで乾燥し, 減圧で溶媒を留去して粗製品 $0.41 \mathrm{~g}$ を得た。これをシリカゲル上でベンゼンを溶離液として 分離し, $3 \mathrm{a}\left(0.33 \mathrm{~g}, 80 \%, \mathrm{mp} 170 \sim 4{ }^{\circ} \mathrm{C}\right)$ を得た. エタノールか ら再結晶して精製品 $\left(0.26 \mathrm{~g}, 63 \%, \mathrm{mp} 188 \sim 9{ }^{\circ} \mathrm{C}\right)$ を得た.

2.3.2 2d の場合 : 2'クロロ-3',5'-シニトロ-2-ニトロメチル-3,4,5,6テトラメチルベンゾフェノン $(2 \mathrm{~d}, 2.00 \mathrm{~g}, 4.74 \mathrm{mmol})$ のメタノ 一ル $100 \mathrm{ml}$, シクロロメタン $150 \mathrm{ml}$ 溶液へ, DBU $(1.44 \mathrm{~g}, 9.48$ $\mathrm{mmol})$ のメタノール $10 \mathrm{ml}$ を室温でよくかきまぜながら添加し た. 同温度で 2 時間かきまぜた後, 約 $500 \mathrm{ml}$ の希塩酸水水中に あけ, シクロロメタンで抽出した. 有機層を水洗した後, 無水硫 酸ナトリウムで乾燥し，減圧で溶媒を留去して5（1.75 g, 96\%， $\mathrm{mp} 136{ }^{\circ} \mathrm{C}$ (d)) を得た. ベンゼン/エタノール $(1 / 2)$ から再結 晶して精製品 $\left(0.83 \mathrm{~g}, 46 \%, \mathrm{mp} 219^{\circ} \mathrm{C}(\mathrm{d})\right)$ を得た.

$5(0.23 \mathrm{~g}, 0.60 \mathrm{mmol})$ に酢酸 $20 \mathrm{ml}$ を加えて煮沸し, 二クロ ム酸ナトリウム二水和物 $(0.36 \mathrm{~g}, 1.20 \mathrm{mmol})$, 水 $0.5 \mathrm{ml}$, 酢酸 $2 \mathrm{ml}$ の溶液を滴下した。 反応混合物を同温度で 4 時間かきまぜ た後, 約 $500 \mathrm{ml}$ の氷水中にあけ, 一夜放置した. 生成した沈殿 物を沪過し粗製品 $0.11 \mathrm{~g}$ を得た. これをシリカゲル上でベンゼン を溶離液として分離し, $3 \mathbf{d}\left(0.07 \mathrm{~g}, 33 \%, \mathrm{mp} \mathrm{201} \sim 10{ }^{\circ} \mathrm{C}\right)$ を得 た. ベンゼンから再結晶して精製品 $(0.04 \mathrm{~g}, 19 \%, \mathrm{mp} 218 \sim 9$ $\left.{ }^{\circ} \mathrm{C}\right)$ を得た.

\section{4 分子内水素身代わり求核置換反応亡酸化反応}

2.4.1 2e 2 $\mathrm{i}$ の場合 : 反応例として，3'-ニトロ-2-ニトロメ チル-3,4,5,6-テトラメチルベンゾフェノン $(\mathbf{2 e})$ について記述す る. $2 \mathrm{e}(0.10 \mathrm{~g}, 0.29 \mathrm{mmol})$ のアセトン $10 \mathrm{ml}$ 溶液へ, 炭酸ナト リウム $(0.06 \mathrm{~g}, 0.58 \mathrm{mmol})$ の水溶液 $1 \mathrm{~m} l$ を室温でかきまぜな がら滴下した. 反応混合物を同温度で 24 時間かきまぜ後, 約 $300 \mathrm{ml}$ の希塩酸水水中に注ぎ, 生成した沈殿物を沪過した. つ いで, 沈殿物に酢酸 $10 \mathrm{~m} l$ 加え煮沸し, 二クロム酸ナトリウム 二水和物 $(0.09 \mathrm{~g}, 0.29 \mathrm{mmol})$, 水 $0.2 \mathrm{ml}$, 酢酸 $1 \mathrm{ml}$ の溶液を 滴下した，反応混合物を同温度で 2 時間かきまぜた後，約 500 $\mathrm{m} l$ の水水中に注ぎ, 一夜放置した. 生成した沈殿物を汇過し粗 製品 $0.08 \mathrm{~g}$ を得た．これをシリカゲル上でベンゼンを溶離液と

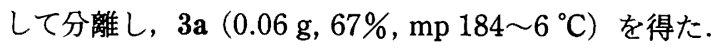

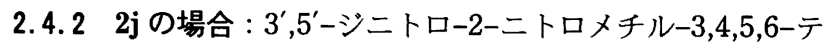
トラメチルベンゾフェノン $(\mathbf{2 j}, 1.00 \mathrm{~g}, 2.58 \mathrm{mmol})$ のメタノー ル $50 \mathrm{ml}$, ジクロロメタン $50 \mathrm{ml}$ 溶液へ, DBU $(0.79 \mathrm{~g}, 5.19$

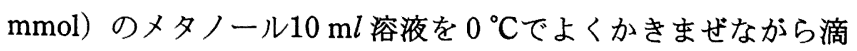
下した。 同温度で 1 時間かきまぜた後, 約 $500 \mathrm{ml}$ の希塩酸水水 中にあけ, ジクロロメタンで抽出した. 有機層を水洗した後, 無 水硫酸ナトリウムで乾燥し, 減圧で溶媒を留去して 6 $(0.84 \mathrm{~g}$, $\left.96 \%, \operatorname{mp} 197^{\circ} \mathrm{C}(\mathrm{d})\right)$ を得た. ベンゼン/メタノール $(1 / 1)$ から 再結晶して精製品 $\left(0.21 \mathrm{~g}, 24 \%, \mathrm{mp} 212{ }^{\circ} \mathrm{C}(\mathrm{d})\right)$ を得た.

6 は 2d の酸化反応と同様な方法で行い, 3d を55\%の収率で得 た.

\section{3 結果と考察}

3.1 ポリメチルベンゾフェノン類の側鎖ニトロ化

$1 \mathrm{a} \sim 1 \mathrm{j}$ を発煙硝酸/無水酢酸系で処理し, 相当する $2-$ ニト
メチル誘導体 $(2 \mathbf{a} \sim 2 \mathbf{j})$ を得た. 合成結果を表 2 に，またその分 析結果を表 3 に示した.

2 の側鎖ニトロ化位置は既報と同様 ${ }^{1} \mathrm{H}-\mathrm{NMR}$ から容易に決定 された4)5). 例えば，1aのオルトメチル基のシグナルは2.07 $\operatorname{ppm}(6 \mathrm{H})$ にあるが，2a では2.03 ppm と僅かに高磁場シフトし ているが，その強度が半减した． $\mathbf{2 b} \sim \mathbf{2} \mathbf{j}$ も同様な傾向が羿めら れた。2-,3-,4-,5-および6-位がメチル置換された 1a, 1d, 1e お よび $1 \mathrm{j}$ の場合，相当する 2 の収率は95〜98\%と良好であった.

一方，3-位が未置換の $1 \mathrm{~b}$ および $1 \mathrm{f}$ の場合，2b および $2 \mathrm{f}$ が主

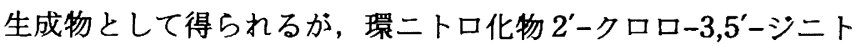

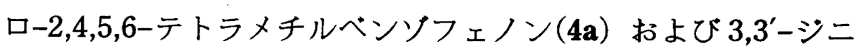
トロ-2,4,5,6-テトラメチルベンソフェノン $(\mathbf{4 b})$ をそれぞれ単離 した9). 3-および 6-位が未置換の 1c, 1g および 1i の場合も，主 生成物として $2 \mathrm{c}, 2 \mathrm{~g}$ および $2 \mathrm{i}$ を得たが, 予想される環ニトロ化 物は単離できなかった，1hでは，他の場合に比べて強い反応条 件を必要とし，2h の収率は50\%に止まった。

\section{2 アントラキノン誘導体 $3 \mathrm{a} \sim 3 \mathrm{f}$ の合成}

3.2 .1 分子内求核置換反応を経る方法: $2 \mathrm{a} \sim 2 \mathrm{~d}$ を塩基で処理 すると, そのニトロメチル基からプロトンが引き抜かれて, カル ボアニオンが生成し，これが $2^{\prime}-$ 位を求核攻撃して，10-ニトロ アントロン誘導体が得られると考えられる. 一方 Steliou ら³ ニトロアルカンをメタノール中, 水酸化カリウムで処理し, つい で過マンガン酸カリウムおよび硫酸マグネシウム水溶液で酸化す ると, カルボニル誘導体が生成することを見いたし，著者ら4)は この条件を 4-ニトロ-1-テトラロン誘導体に適用し, テトラリン-1,4シオン誘導体を好収率で得た．これらのことより 2a～2dよりア ントラキノン誘導体の合成を検討した。

2a〜2c と DBU をメタノールハシクロロメタン中で 4 時間煮沸 し, ついで $0 \sim 5{ }^{\circ} \mathrm{C}$ で水酸化カリウム, 過マンガン酸カリウムお よび硫酸マグネシウムの水溶液を加え 2 時間反応させて酸化し, 相当するアントラキノン誘導体 $\mathbf{3 a} \sim \mathbf{3}$ を高収率で得た（図式 2)結果を表 4 に示した．この場合，第一段階で生成するアント ロン誘導体の単離精製は困難であった.

2d の場合は，DBU 処理でアントロン誘導体 5 を収率 96\%で 単離した.（図式 3)このものを二クロム酸ナトリウム/酢酸/水系 で煮沸, 酸化して3d を収率 33\%で得た。

Table 2 Nitration of benzophenones $(\mathbf{1 a} \sim \mathbf{1 j})$ with fuming nitric acid in acetic anhydride

\begin{tabular}{ccccc} 
& $\begin{array}{c}\text { Molar ratio } \\
\text { of } \mathrm{HNO}_{3} / l\end{array}$ & \multicolumn{2}{c}{ Reaction conditions } & \multicolumn{2}{c}{ Yield of 2} \\
$(\mathrm{C})$ & $(\mathrm{C})$ & $(\%)$ \\
\hline a & 2.2 & $0 \sim 5$ & 10 & 98 \\
b & 3.5 & $0 \sim 5$ & 15 & $\left.76^{a}\right)$ \\
c & 3.5 & r.t. & 50 & 45 \\
d & 2.5 & r.t. & 8 & 97 \\
e & 2 & r.t. & 5 & 95 \\
f & 2 & r.t. & 24 & $57^{b)}$ \\
g & 3.5 & r.t. & 24 & 60 \\
h & 4 & $40 \sim 45$ & 24 & 50 \\
i & 2 & r.t. & 3 & 82 \\
j & 3.5 & r.t. & 5 & 98
\end{tabular}

a) By-product 4a: $22 \%$.

b) By-product $4 \mathrm{~b}: 25 \%$. 
Table 3 Characterization of compounds $(\mathbf{2 a} \sim \mathbf{2 j}, \mathbf{4 a}$ and $\mathbf{4 b})$

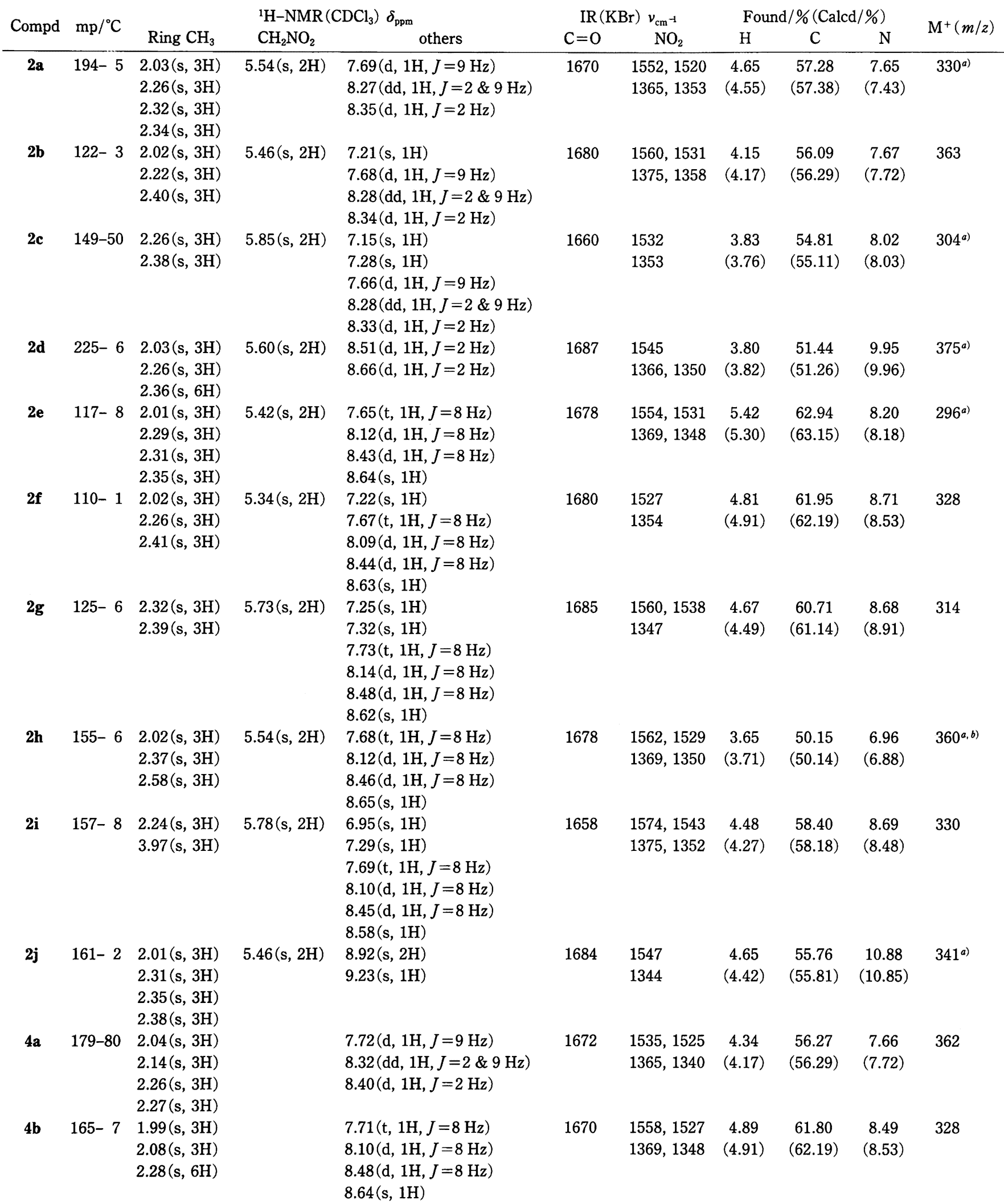

a) $\mathrm{M}^{+}$was not observed. $m / z=\mathrm{M}^{+}-46\left(\mathrm{NO}_{2}\right)$.

b) Isotopic peak by ${ }^{81} \mathrm{Br}$ was also observed. za 5 ${ }^{10 a)}$ は水酸化カリウム存在下ニトロベンゼンとクロロメチル 


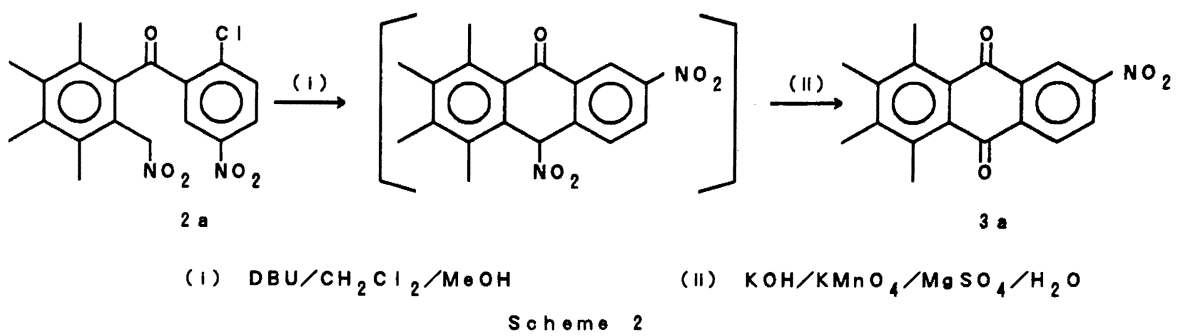

Table 4 Intramolecular $\operatorname{Ar}_{\mathrm{N}}$ reaction and oxidation ${ }^{a)}$ of benzophenones $(\mathbf{2 a} \sim \mathbf{2 c})$

\begin{tabular}{ccc} 
Run & Compd. 2 & $\begin{array}{c}\text { Product } \\
\text { (Isolated yield/\%) }\end{array}$ \\
\hline 1 & $\mathbf{2 a}$ & $\mathbf{3 a}(80)$ \\
2 & $\mathbf{2 b}$ & $\mathbf{3 b}(85)$ \\
3 & $\mathbf{2 c}$ & $\mathbf{3 c}(83)$
\end{tabular}

a) 1) $\mathrm{DBU}$ (1 mol. amt.) in $\mathrm{MeOH} / \mathrm{CH}_{2} \mathrm{Cl}_{2}(1: 1)$, reflux, $4 \mathrm{~h}$.

2) $\mathrm{KOH}$ (1 mol. amt.) $/ \mathrm{KMnO}_{4}$ (1 mol. amt.) $/ \mathrm{MgSO}_{4}(1$ mol. amt.) $/ \mathrm{H}_{2} \mathrm{O}, 0 \sim 5{ }^{\circ} \mathrm{C}, 2 \mathrm{~h}$.

置換反応と名付けた．この反応はクロロメチルフェニルスルホン に塩基が作用して生成したカルボアニオンがニトロベンゼンを求 核的に攻撃して $\sigma^{\mathrm{H}}$ 付加体を生成し，これより塩基による塩化水 素の脱離, プロトン化を経て進行すると考えられている10).

このことにより 2 -位に塩素原子をむたない $2 \mathrm{e} \sim 2 \mathbf{j}$ の場合む， 塩基の作用により相当するアントロン誘導体が生成し，ついで酸 化によりアントラキノン誘導体に変化すると考えられる.

種々の反応条件を検討した結果，つぎの方法が良好であった。

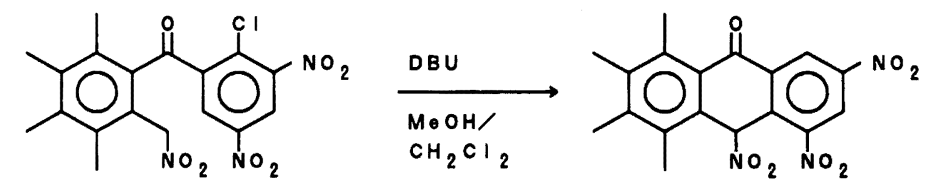

$2 d$ 5 $96 \%$

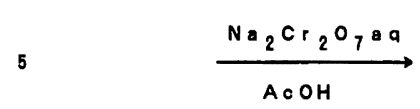<smiles>Cc1c(C)c(C)c2c(c1C)C(=O)c1cc([N+](=O)[O-])cc([N+](=O)[O-])c1C2=O</smiles>
schome 3 $3 \mathrm{~d}$ $33 \%$

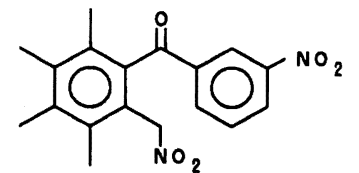

20

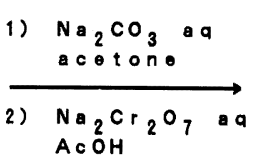

scheme

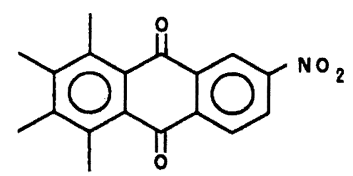

3 .

Table 5 Intramolecular vicarious nucleophilic substitution of hydrogen and oxidation of benzophenones (2e $\sim 2 \mathbf{i})$

\begin{tabular}{|c|c|c|c|c|c|}
\hline Compd. & $\begin{array}{c}\text { Base }^{a)} \\
\text { (Temp., Time) }\end{array}$ & Solvent & $\begin{array}{c}\text { Oxidant } t^{b)} \\
\text { (Temp., Time) }\end{array}$ & Solvent & $\begin{array}{l}\text { Product } \\
\text { (Yield/\% }\end{array}$ \\
\hline $2 e$ & $\begin{array}{c}\mathrm{DBU} \\
\left(0^{\circ} \mathrm{C}, 2 \mathrm{~h}\right)\end{array}$ & $\mathrm{MeOH} / \mathrm{CH}_{2} \mathrm{Cl}_{2}$ & $\begin{array}{c}\mathrm{KMnO}_{4} / \mathrm{KOH} \\
\left(0^{\circ} \mathrm{C}, 2 \mathrm{~h}\right)\end{array}$ & $\mathrm{MeOH} / \mathrm{CH}_{2} \mathrm{Cl}_{2}$ & $3 \mathbf{a}(37)$ \\
\hline $2 \mathbf{e}$ & $\begin{array}{l}\mathrm{Na}_{2} \mathrm{CO}_{3} \\
\text { (r.t., } 24 \mathrm{~h} \text { ) }\end{array}$ & Acetone & & & $3 \mathbf{a}(55)$ \\
\hline $2 \mathbf{e}$ & & $:$ & $\begin{array}{l}\mathrm{Na}_{2} \mathrm{Cr}_{2} \mathrm{O}_{7} \\
\text { (reflux, 2h) }\end{array}$ & $\mathrm{AcOH}$ & $\mathbf{3 a}(67)$ \\
\hline $2 f$ & & : & & & $3 \mathbf{b}(63)$ \\
\hline $2 g$ & & $:$ & & & $3 c(49)$ \\
\hline $2 \mathbf{h}$ & & $:$ & & & $3 \mathbf{e}(67)$ \\
\hline $2 \mathrm{i}$ & & : & & & $3 \mathbf{f}(78)$ \\
\hline
\end{tabular}

a) Molar ratio compound 2/base (1/2).

b) Molar ratio compound 2/oxidant (1/1). 
2e〜2i と炭酸ナトリウムをアセトン/水系中, 室温で処理し，こ れを希塩酸中に注ぎ，ついで汇別した沈殿物を，酢酸/水系中， 二クロム酸ナトリウムで煮沸, 酸化し, アントラキノン誘導体 （3a〜3c，3e および 3f）を得た.（図式 4)結果を表 5 に示した。 第一段階での沈殿物は, NMR 測定で複雑な混合物であり, ア
ントロン誘導体の単離は行わなかった。

一方， $2 \mathbf{j}$ は DBU で処理して，中間体であるアントロン誘導体 6 を収率 $96 \%$ で得た。このものを二クロム酸ナトリウムで酸化 して，3d を収率 55\%で得た。（図式 5）3a〜3f, 5 および 6 の分 析結果を表 6 に示した.

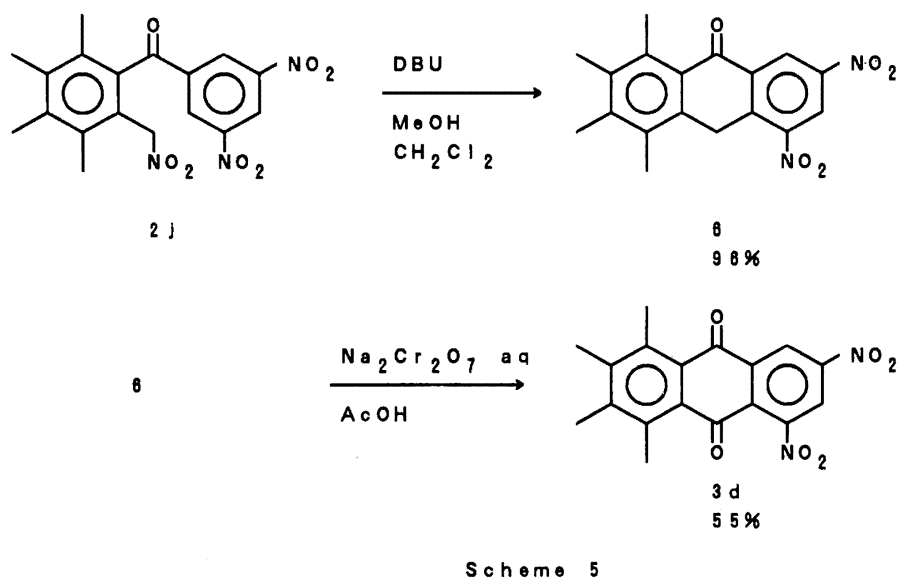

Table 6 Characterization of compounds ( $3 \mathbf{a} \sim \mathbf{3 f}, \mathbf{5}$ and $\mathbf{6})$

\begin{tabular}{|c|c|c|c|c|c|c|c|c|c|}
\hline \multirow{2}{*}{\multicolumn{2}{|c|}{ Compd $\mathrm{mp} /{ }^{\circ} \mathrm{C}$}} & \multicolumn{2}{|c|}{${ }^{1} \mathrm{H}-\mathrm{NMR}\left(\mathrm{CDCl}_{3}\right) \delta_{\mathrm{ppm}}$} & \multicolumn{2}{|c|}{$\mathrm{IR}(\mathrm{KBr}) v_{\mathrm{cm}^{-1}}$} & \multicolumn{3}{|c|}{ Found $/ \%(\mathrm{Calcd} / \%)$} & \multirow{2}{*}{$\mathrm{M}^{+}(m / z)$} \\
\hline & & Ring $\mathrm{CH}_{3}$ & others & $\mathrm{C}=\mathrm{O}$ & $\mathrm{NO}_{2}$ & $\mathrm{H}$ & $\mathrm{C}$ & $\mathrm{N}$ & \\
\hline \multirow[t]{2}{*}{$\mathbf{3 a}$} & $188-9$ & $2.41(\mathrm{~s}, 6 \mathrm{H})$ & $8.27(\mathrm{~d}, 1 \mathrm{H}, J=9 \mathrm{~Hz})$ & 1672 & 1527 & 4.96 & 69.51 & 4.82 & 309 \\
\hline & & $2.69(\mathrm{~s}, 3 \mathrm{H})$ & $8.47(\mathrm{dd}, 1 \mathrm{H}, J=2 \& 9 \mathrm{~Hz})$ & & 1321 & $(4.89)$ & $(69.89)$ & $(4.53)$ & \\
\hline \multirow[t]{2}{*}{$\mathbf{3 b}$} & $179-80$ & $2.39(\mathrm{~s}, 3 \mathrm{H})$ & $8.05(\mathrm{~s}, 1 \mathrm{H})$ & 1675 & 1534 & 4.55 & 68.74 & 4.70 & 295 \\
\hline & & $2.49(\mathrm{~s}, 3 \mathrm{H})$ & $8.40(\mathrm{~d}, 1 \mathrm{H}, J=8 \mathrm{~Hz})$ & & 1323 & $(4.44)$ & $(69.15)$ & $(4.74)$ & \\
\hline \multirow[t]{5}{*}{$3 c$} & $205-7$ & $2.47(\mathrm{~s}, 6 \mathrm{H})$ & $8.09(\mathrm{~s}, 1 \mathrm{H})$ & 1680 & 1529 & 4.12 & 67.16 & 4.83 & 281 \\
\hline & & & $8.11(\mathrm{~s}, 1 \mathrm{H})$ & & 1327 & $(3.94)$ & $(68.33)$ & $(4.98)$ & \\
\hline & & & $8.48(\mathrm{~d}, 1 \mathrm{H}, J=8 \mathrm{~Hz})$ & & & & & & \\
\hline & & & $8.57(\mathrm{dd}, 1 \mathrm{H}, J=2 \& 8 \mathrm{~Hz})$ & & & & & & \\
\hline & & & $9.10(\mathrm{~d}, 1 \mathrm{H}, J=2 \mathrm{~Hz})$ & & & & & & \\
\hline 3d & $218-9$ & $2.42(\mathrm{~s}, 6 \mathrm{H})$ & $8.67(\mathrm{~d}, 1 \mathrm{H}, J=2 \mathrm{~Hz})$ & 1676 & 1545 & 3.83 & 61.11 & 6.75 & 354 \\
\hline \multirow{2}{*}{$3 \mathbf{e}$} & & $2.66(\mathrm{~s}, 3 \mathrm{H})$ & $8.51(\mathrm{~d}, 1 \mathrm{H}, J=8 \mathrm{~Hz})$ & & 1332 & $(3.23)$ & $(54.57)$ & $(3.74)$ & \\
\hline & & $2.70(\mathrm{~s}, 3 \mathrm{H})$ & $8.90(\mathrm{~s}, 1 \mathrm{H})$ & & & & & & \\
\hline \multirow[t]{5}{*}{$3 \mathbf{f}$} & $234-5$ & $2.38(\mathrm{~s}, 3 \mathrm{H})$ & $7.66(\mathrm{~s}, 1 \mathrm{H})$ & 1682 & 1529 & 3.90 & 64.83 & 4.63 & 297 \\
\hline & & $4.05(\mathrm{~s}, 3 \mathrm{H})$ & $8.12(\mathrm{~s}, 1 \mathrm{H})$ & & 1334 & (3.73) & $(64.65)$ & $(4.71)$ & \\
\hline & & & $8.46(\mathrm{~d}, 1 \mathrm{H}, J=8 \mathrm{~Hz})$ & & & & & & \\
\hline & & & $8.54(\mathrm{dd}, 1 \mathrm{H}, J=2 \& 8 \mathrm{~Hz})$ & & & & & & \\
\hline & & & $9.07(\mathrm{~d}, 1 \mathrm{H}, J=2 \mathrm{~Hz})$ & & & & & & \\
\hline \multirow[t]{4}{*}{5} & $219(d)$ & $2.38(\mathrm{~s}, 3 \mathrm{H})$ & $7.95(\mathrm{~s}, 1 \mathrm{H})$ & 1671 & 1561 & 3.91 & 56.28 & 10.80 & $339^{b)}$ \\
\hline & & $2.41(\mathrm{~s}, 3 \mathrm{H})$ & $9.07(\mathrm{~d}, 1 \mathrm{H}, J=2 \mathrm{~Hz})$ & & 1346 & $(3.92)$ & $(56.11)$ & $(10.91)$ & \\
\hline & & $2.64(\mathrm{~s}, 3 \mathrm{H})$ & $9.22(\mathrm{~d}, 1 \mathrm{H}, J=2 \mathrm{~Hz})$ & & & & & & \\
\hline & & $2.69(\mathrm{~s}, 3 \mathrm{H})$ & & & & & & & \\
\hline 6 & $212(d)$ & $2.35(\mathrm{~s}, 3 \mathrm{H})$ & $4.56(\mathrm{~s}, 2 \mathrm{H})$ & 1657 & 1537 & 4.45 & 63.68 & 8.31 & 340 \\
\hline
\end{tabular}

a) Isotopic peak by ${ }^{81} \mathrm{Br}$ was also observed.

b) $\mathrm{M}^{+}$was not observed. $m / z=\mathrm{M}^{+}-46\left(\mathrm{NO}_{2}\right)$. 


\section{4 結 論}

ポリメチルベンゾフェノン類 $(\mathbf{1})$ を発煙硝酸/無水酢酸系で反応 させると,アシル基のオルト位メチル基に優先してニトロ化が起 こり，側鎖ニトロ化物 (2) を与えた．2-,3-,4-,5-および 6-位に メチル置換された $1 \mathrm{a}, 1 \mathrm{~d}, 1 \mathrm{e}$ および $1 \mathrm{j}$ は定量的に 2 が得られた. 3-位が未固換の場合でも，2 を主生成物として単離した。特に， 1b, 1f では 3-位にニトロ化された環ニトロ化物を少量単離した． 側鎖ニトロ化物 $\mathbf{2 a} \sim \mathbf{2 c}$ を DBU で処理し，過マンガン酸カリ ウムで酸化する One Pot 反応では，相当するアントラキノン誘 導体を好収率で得た。特に，2d では，分子内求核置換反応生成 物であるこトロアントロン体(5) を単離した.

側鎖ニトロ化物 2e～2i での炭酸ナトリウムによる分子内水素 身代わり求核置換反応と二クロム酸ナトリウムによる酸化反応 は，相当するアントラキノン誘導体を与えた．2j は分子内水素 身代わり求核置換反応生成物 (6) を選択的に与えた.

ポリメチルベンゾフェノン類から発煙硝酸/無水酢酸系による 側鎖ニトロ化，塩基による環化反応，そして酸化を行うことで， ポリメチルアントラキノン誘導体を容易に合成できた。

1) a) K. Schofield, “Aromatic Nitration", Cambridge University Press, London(1980) p. 171.

b) S. R. Hartshorn, Chem. Soc. Rev., 3, 169(1974).

c) R. B. Moodie, K. Schofield, Acc. Chem. Res., 9, $287(1976)$.

d) H. Suzuki, Synthesis, 1977, 217. e) 鈴木仁美, 有合化, 37, 290(1979).

2) a) G. A. Olah, Y. D. Vankar, B. G. B. Gupta, Synthesis, 1979,36

b) D. Seebach, E. W. Colvin, F. Lehr, T. Weller, Chimia, 33, 1(1979).

c) N. Ono, A. Kamimura, I. Hamamoto, A. Kaji, J. Org. Chem., 50, 3692(1985).

d) N. Ono, A. Kaji, Synthesis, 1986, 695.

3) K. Steliou, M. Poupart, J. Org. Chem., 50, 4971(1985).

4) T. Keumi, T. Morita, K. Teramoto, H. Takahashi, H. Yamamoto, K. Ikeno, M. Hanaki, T. Inagaki, H. Kitajima, J. Org. Chem., 51, 3439(1986).

5) T. Keumi, T. Inagaki, N. Nakayama, M. Taniguchi, T. Morita, H. Kitajima, J. Org. Chem., 54, 4034(1989).

6) T. Keumi, K. Matsuura, N. Nakayama, T. Tsubota, T. Morita, I. Takahashi, H. Kitajima, Tetrahedron, 49, 537(1993).

7) D. G. Davies, P. Hodge, P. Yares, J. Chem. Soc., Perkin Trans. 1, 1974, 2399.

8) a) W. L. Mosby, J. Am. Chem. Soc., 74, 2564(1952). b) G. Baddeley, G. Holt, S. M. Makar, J. Chem. Soc., 1952, 2415.

9）毛海 敬, 森田俊夫, 川崎美穂, 邱 壬彰, 北嶋英彦, 井上吉教, 日化, 1991, 199 .

10) a) M. Makosza, J. Golinski, Tetrahedron Lett., 37, 3495(1978).

b) M. Makosza, T. Glinka, J. Org. Chem., 48, 3860(1983). c) M. Makosza, J. Winiarski, Acc. Chem. Res., 20, 282 (1987).

d) M. Makosza, K. Sienkiewicz, J. Org. Chem., 55, 4979(1990).

\section{Ortho-Selective Side-Chain Nitration of Polymethylbenzophenones and its Application to the Synthesis of Anthraquinones}

\section{Toshio Morita*, Kazuyo FuJII, Kiyomi TAgA, Hiroki TsuKamoto, Ichiro TAKAHASHI, Takashi KEUMI and Hidehiko KITAJIMA \\ Department of Applied Chemistry and Biotechnology, Faculty of Engineering, \\ Fukui University; Bunkyo, Fukui-shi 910 Japan}

Polymethylbenzophenones $(\mathbf{1} \mathbf{a} \sim \mathbf{1 j})$ reacted with fuming nitric acid in acetic anhydride to give 2(nitromethyl) polymethylbenzophenones $(\mathbf{2} \mathbf{a} \sim \mathbf{2 j})$ in satisfactory isolated yields. Compounds $\mathbf{2 a} \sim \mathbf{2 d}$ underwent the intramolecular nucleophilic substitution/cyclization by equimolar amount of 1,8-diazabicyclo[5.4.0] undec-7-ene and subsequent oxidation by $\mathrm{KMnO}_{4}$ in $\mathrm{MeOH} / \mathrm{CH}_{2} \mathrm{Cl}_{2}$ or by $\mathrm{Na}_{2} \mathrm{Cr}_{2} \mathrm{O}_{7}$ in $\mathrm{AcOH}$ to afford the corresponding polysubstituted anthraquinones $(\mathbf{3 a} \sim \mathbf{3 d})$ in good isolated yields. Compounds $2 \mathbf{e} \sim 2 \mathbf{j}$ underwent the intramolecular vicarious nucleophilic substitution of hydrogen/cyclization by 2 molar amounts of $\mathrm{Na}_{2} \mathrm{CO}_{3}$ in acetone and subsequent oxidation by $\mathrm{Na}_{2} \mathrm{Cr}_{2} \mathrm{O}_{7}$ in $\mathrm{AcOH}$ to give the corresponding polysubstituted anthraquinones $\mathbf{3 a} \sim \mathbf{3 f}$. 